\title{
THE EMPOWERMENT OF SMALL AND MEDIUM ENTERPRISES IN CILEDUG DISTRICT, TANGERANG CITY THROUGH TRAINING ON TRADEMARK
}

\author{
Bambang PUJIYONO* and Iman Tri WIBOWO \\ Budi Luhur University, Indonesia \\ *bambang.pujiono@budiluhur.ac.id
}

\begin{abstract}
This article discusses about the community service held to improve the understanding of the micro, small, and medium entreprises (SMEs) owners towards the existence of trademark. The partners in this program covers SMEs in Ciledug District, Tangerang City, focusing on startup ones. The problems faced by the owners spanned from the difficulty in introducing their products, limited understanding about trademark, about how to build the brand of their products, to the limitation information on how to register their brand for intellectual property rights. Brand can be harnessed to show distinct character between one product to other similar products. However, the branding developed by the enterprises have been conducted modestly. In order to overcome those problems, the community service provided training and assistance regarding the creation and the protection of trademark. The methods used in the program are direct observation on the SMEs management appointed by the Ciledug District Administration, continued with training sessions including meeting, presentation, and mentoring. The instructors explained how the brand is not just a slogan, image or sound since a brand represent philosophical meaning and value. The instructors also explained how a well brand development could be one of prevention measure of any unwanted external counterfeiting activities in the future that will disadvantage the participant SMEs. The understanding on the importance of a good branding development and trademark become the basis for participant SMEs to implement at least six various efforts to increase the awareness of consumers.
\end{abstract}

Keywords: Training, Trademark, SMEs

\section{BACKGROUND}

Small and Medium Enterprises (SMEs) that were partners in the community service program are SMEs in Ciledug District that relatively were still at beginner level. Based on the results of observation and interview with SMEs manager in Ciledug District Administration, there were 15 startup businesses, most of which are in the food and beverage sector. SMEs have an important role in economic development because of the relatively high level of labor absorption and relatively small investment capital requirements. The benefits of SMEs have been proven as to be able to encourage economic growth in the community. This is due to the flexibility SMEs have more in adapting and responding to the dynamic of change in the market. However, the increasing number of SMEs has not been corresponded to the development of the quality of SMEs.

The SMEs faced the common challenge faced by any startup business, i.e. the lack of ability to maintain the sustainability of the business. The competitiveness and ability of SMEs need to be further improved in order to take advantage of the current free trade system. The system can be used as an opportunity to introduce their superior products in the global market, as well as to participate and even play an actual role in the system. However, not all SMEs can take advantage of such opportunity to penetrate a wider market or compete in an increasingly global market. Although the current market has opened spaces for more opportunities, trade liberalism does not automatically help and even poses a threat to Small and Medium Enterprises (SMEs). To anticipate this threat, SMEs are required to be creative and innovative. SMEs are also challenged to take steps to produce goods that in terms of quality are not inferior to those of large companies.
There are at least 10 (ten) reasons why branding is important for SMEs. First, brand will stick in memory. Brand is assets. Brand can arouse the emotional side of consumers. Brand can create totality in business services. Brand makes it easier for customers to find our business. Brand creates personality. Brand has the power to attract consumers. Brand can save business costs. Brand also affects buying behavior. Last but not least, brand and personal branding are closely related. The purpose of the activity in this community service program is to provide awareness to business actors regarding product brands created as an effort to protect intellectual property. The benefit of the activity is for the business actors to create and register their product brands.

\section{METHODS}

The observation was followed by a meeting in the form of presentations and mentoring. The first meeting was conducted in form of presentations given by the lecturers. The second meeting was conducted in form of mentoring by lecturers and students.

\section{Observation}

Observation activities were carried out at the beginning of the Semester 2 of Academic Year 2019/2020. Based on the observation, it was conclusive that the obstacles faced by SMEs in Ciledug District, Tangerang City, among others, was about products that were not well known to wider community. This has impacted on sales difficulties. After discussing with the SMEs Management of Ciledug District, it was decided that community service activities was to be carried out immediately, and had to covered branding skill and the comprehension of trademark. Therefore, the management of SMEs hoped 
that this service activity would continue to resolve some of these obstacles.

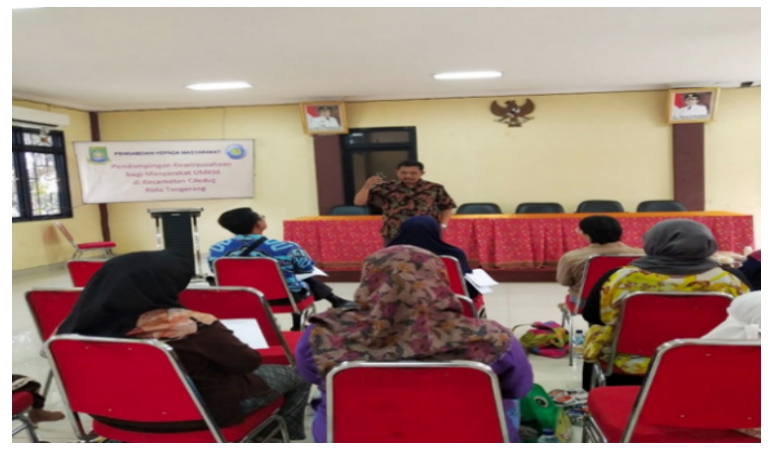

Picture 1. Presentation by instructor on understanding trademarks before the participants of the training

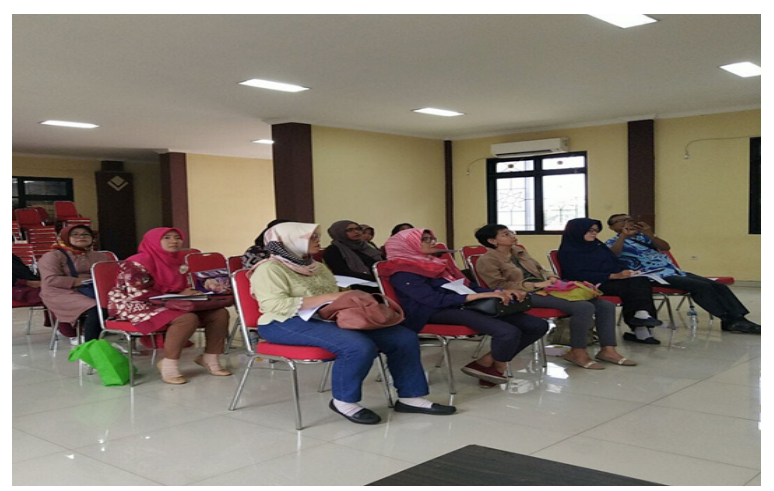

Picture 2. The participation of the trainees

\section{Presentation and Mentoring}

The method that next methods used in this community service activity were presentation in the Ciledug District Office Hall and direct assistance to each participant or trainee.

\section{RESULTS AND DISCUSSION}

At the onset of the meeting, some participants have brought products with brands. Some brands that have been labeled on their products were still limited to what was important. The branding has yet involve a philosophical explanation. The visualization of the brand attached to the product still required some improvements. The visualization was considerably simple, and the design was not yet attractive. The coloring, color composition, and the use of images looked modest. In general, the branding displayed that the product label has not meet the standard criteria.

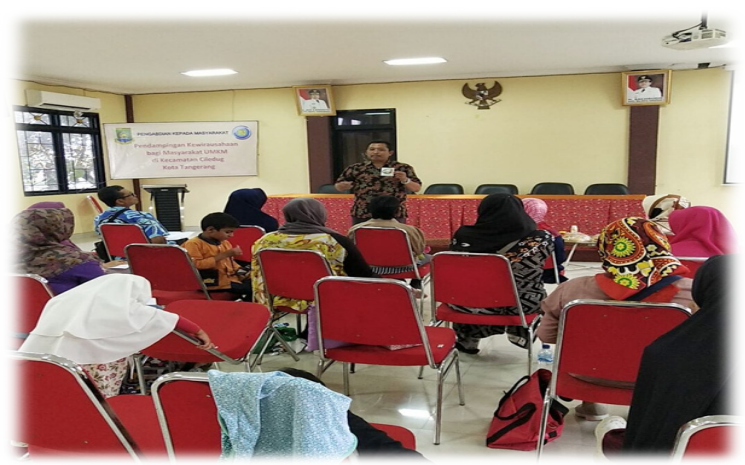

Picture 3. The instructor provides an explanation of how a product is trademarked
As explained, conceptually wise, the brand must be meaningful and become an important assertion about the existence of the brand itself. After the explanation, the trainees realized that if the trademark or product was not developed properly and protected, it would result on negative impacts for business sustainability. First, the quality of products with various trademark counterfeiting are lower than the original ones. Second, the intention of counterfeiting activities involve objectives to get absolute profits quickly. Both would actually detriment entrepreneurs such as Small and Medium Enterprises (SMEs) that produce original goods.

The efforts to achieve brand awareness, both at the recognition and recall level, involve two activities: the process to acquire the brand identity, and the process to associate it with a particular class of product. Durianto, et al. (2004), revealed that the level of consumer awareness of a brand can be increased through various efforts as follows:

1. A brand must be able to convey a message that is easy to be remembered by consumers. The message must be different compared to other brands. In addition, the message must have a relationship with the brand and product category.

2. Companies are advised to use jingle songs and catchy slogans so that the brand is easier for consumers to remember.

3. The symbol used by the company should have a relationship with the brand.

4. Companies can use the brand to expand the product, so that the brand will be remembered by consumers.

5. Companies can strengthen brand awareness through a cue that fits the product category, brand, or both.

6. Forming memories in the mind of consumers will be more difficult than introducing a new product, so companies must always repeat to improve consumer memory of the brand.

With regard to this, it is necessary to protect the trademark of goods produced by Small and Medium Enterprises (SMEs) based on Law no. 15 of 2001 concerning Brands. At the end of the training session, participants were given an explanation of the technique of registering business brands and trademarks online. Although the training was only an introduction, by taking the enthusiasm of the trainees into account, it is hoped and agreed that at the next community service activity, the training would cover explanation and assistance in applying steps to make a brand and register it to the intellectual property protection office.

\section{CONCLUSION}

Trademark recognition training activities for SMEs owners are very necessary. A brand is not just a slogan, image, or sound. A brand represent philosophical meaning and value. Through the branding, a product can be recognized easily. The brand will help businesses to get a profit on the sale of their products. 


\section{ACKNOWLEDGEMENT}

This event and publication would not be able to run smoothly without the help of several parties. The topmost gratitude is solely to The Almighty - only with His Bless, the workshop and all other process prior to and post event can be held without any significant obstacles. A strong coordination and well organized administration have also contributed much to the event.

\section{REFERENCES}

Durianto, D., Sugiarto, and Budiman, LJ. (2004). Brand Equity Ten: Strategi Memimpin Pasar. PT.Gramedia Pustaka Utama, Jakarta.
Kotler, P. (2005). Manajemen Pemasaran, Ed. 11 (I). PT. Indeks Gramedia, Jakarta.

Kussudyarsana. (2016). Persepsi Konsumen Atas Merek Lokal dan Asing pada Kategori Produk Hedonik dan Utilitarian Benefit. Benefit: Jurnal Manajemen dan Bisnis, Vol. 1 (1), 48 - 56.

Tjiptono, F. (2008). Strategi Pemasaran, Ed. 3. Penerbit Andi, Yogyakarta.

Badan Pusat Statistik, Kota Tangerang. Kecamatan Ciledug dalam Angka Tahun 2018.

Undang Undang No. 15 Tahun 2001 tentang Merek. 